\title{
ANTARA BENCI DAN RINDU: HUBUNGAN INDONESIA-MALAYSIA DAN ISU TENAGA KERJA ILEGAL DI MALAYSIA
}

\author{
Oleh: Mohammad Maiwan*
}

\begin{abstract}
The objective of this research is to get adeguate explanation and understanding to Indonesia-Malaysia relation in related to solving problem of the illegal workers. The method was using descriptive and qualitative. This study shows, that illegal workers was a serious problem which give impact to the Indonesia-Malaysia relations. In Malaysia contexs, its can be impact to the economy, social, security and etc. Nevertheless, Indonesian government must be take integrative and comprehensive program through good recruitment, regulation, advocation and administrative services.
\end{abstract}

Key Words: Migrant workers, illegal, Indonesia-Malaysia relations.

\section{Latar Belakang}

Perkembangan hubungan antara Indonesia-Malaysia selama ini diwarnai adanya dinamika yang bersifat turun naik. Walaupun secara umum hubungan kedua negara tersebut berlangsung cukup harmonis dan lancar, namun pada waktuwaktu tertentu terkadang mengalami gangguan, sehingga menimbulkan beberapa ketegangan. Pada satu waktu nampak terasa erat dan dekat, namun secara tiba-tiba terkadang berubah menjadi renggang. Bahkan dalam beberapa tahun belakangan, hubungan itu mengalami beberapa masalah yang bersumber dari adanya insiden-insiden kecil yang sesungguhnya tidak perlu terjadi. Pada tahap tertentu kestabilan dan keharmonisan hubungan Indonesia-Malaysia agak sukar diduga. Dapat dilukiskan bahwa hubungan dua bangsa serumpun ini terentang antara "benci dan rindu".

Adanya kedekatan-kedekatan yang berasal dari berbagai persamaan, baik yang bersifat geografis, sosial, historis, maupun kultural ternyata tidak secara otomatis menjadi jaminan bahwa hubungan keduanya senantiasa dapat berjalan stabil dan lancar (Saw dan Kesavapany 2004: 11). Dengan kata lain, faktor-faktor kesamaan saja, tidak cukup memadai untuk membantu menyelesaikan semua masalah.

\footnotetext{
* Dosen pada Program Studi PPKn, Fakultas Ilmu Sosial Universitas Negeri Jakarta
} 
Sebagai dua buah negara yang berdaulat, masing-masing justru memiliki perbedaan kepentingan, persepsi, dan cara pandang tersendiri atas masalah-masalah yang dihadapi.

Salah satu isu penting yang seringkali menimbulkan gangguan dalam hubungan Indonesia-Malaysia adalah masalah tenaga kerja ilegal atau dalam Bahasa Malaysia sering disebut sebagai pendatang haram. Rumitnya penanganan TKI bukan saja semata-mata, berasal dari pihak Indonesia saja, namun juga dari pihak Malaysia. Salah satunya terjadi, di samping disebabkan karena adanya perbedaan sudut pandang, juga karena adanya kepentingan yang berbeda.

Berdasarkan kenyataan di atas, maka permasalahannya adalah, bagaimana dinamika hubungan Indonesia-Malaysia selama ini dikaitkan dengan isu tenaga kerja ilegal? Dengan kata lain, bagaimana isu TKI mempengaruhi hubungan Indonesia-Malaysia selama ini?

\section{Hubungan Indonesia-Malaysia}

Secara historis hubungan IndonesiaMalaysia sesungguhnya telah berlangsung lama. Jauh sebelum terbentuknya negara Indonesia maupun Malaysia moderen yang berdaulat, hubungan kedua-dua masyarakat negara tersebut telahpun berlangsung secara alamiah selama ratusan tahun yang lalu. Pada hakikatnya, jalinan hubungan antara Indonesia dan Malaysia terjadi disebabkan beberapa hal. Pertama, adalah kedudukan geografis. Posisi geografis Malaysia yang sangat dekat dengan wilayah Indonesia, khususnya Indonesia bagian Barat, yakni Sumatera, Kalimantan, dan Jawa menyebabkan arus mobilitas dari dan ke wilayah tersebut sedari dulu sangatlah tinggi.

Kedua, disebabkan oleh hakikat bahwa kedua-dua masyarakat negara tersebut merupakan rumpun bangsa yang sama, yakni bangsa Melayu, yang memiliki bahasa dan budaya yang sama, yang berasal dari keturunan yang sama, serta diikat oleh jalinan kekerabatan yang erat. Bertitik tolak dari konsep "keserumpunan" dan persaudaraan inilah hubungan Indonesia-Malaysia terasa sangat khas. Pada masa lalu, penekanan pada dimensi persaudaraan atas dasar keserumpunan ini begitu menonjol sehingga melahirkan kesamaan kepentingan (Omar 2001: 33).

Selanjutnya, unsur-unsur kedekatan di atas menjadi semakin diperkuat lagi dengan adanya unsur ketiga, yakni kesamaan agama, di mana masyarakat kedua negara mayoritas memeluk agama Islam. Di samping ketiga unsur di atas, hubungan Indonesia-Malaysia sangat 
dipengaruhi oleh unsur keempat, yakni kedudukan Indonesia sendiri. Sebagai negara yang besar, baik dari segi jumlah penduduk maupun luas wilayah, Indonesia mempersepsikan dirinya sebagai pemimpin dari negara-negara di kawasan Asia Tenggara (Suryadinata 1991: 13). Dengan jumlah penduduk sekitar 240 juta orang, keluasan wilayah sekitar 2 juta km persegi, serta panjang dari ujung Barat di Pulau Sabang sampai ujung Timur di Merauke Papua yang mencapai sekitar $5.000 \mathrm{~km}$, yang mencakup 16.000 pulau-pulau besar dan kecil, menjadikan Indonesia merupakan suatu negara besar yang nyaris tidak ada bandingannya di kawasan Asia Tenggara.

Sebagai akibat dari persepsi semacam itu, bagi pihak Indonesia, dalam beberapa kesempatan, sejumlah inisiatif politik yang terkadang muncul dari pihak Malaysia ataupun negara-negara lain di kawasan Asia Tenggara seringkali dipersepsikan suatu bentuk tindakan untuk mencoba menyaingi kedudukan Indonesia sebagai pemimpin sekaligus negara besar di kawasan Asia Tenggara.

Pada satu pihak, Indonesia lebih memandang dirinya sebagai "kakak", sedang Malaysia sebagai “adik" yang dalam batas-batas tertentu harus tahu diri. Sementara di pihak lain, Malaysia dengan kemajuan-kemajuan dan keberhasilan ekonomi yang dicapainya, justru bersikap sebaliknya, di mana mereka memandang dirinya dengan keyakinan tertentu sebagai negara yang setahap lebih maju dan canggih ketimbang Indonesia. Hal inilah yang kemudian oleh Indonesia dianggap sebagai sikap arogan, sehingga tidak jarang menimbulkan ketegangan.

Dalam perkembangannya, hubungan kedua negara kemudian mengalami pasang surut. Berbagai isu yang muncul tidak jarang mencetuskan kontroversi, bahkan ketegangan pada kedua belah pihak, mulai dari isu perbatasan, pembalakan liar, kabut pembakaran hutan, warisan seni budaya, pemukulan wasit, isu askar perbatasan, sampai dengan isu ketenagakerjaan. Salah satu isu penting yang perlu dihadapi kedua negara adalah, isu Tenaga Kerja Indonesia (TKI), khususnya tenaga kerja ilegal di Malaysia.

\section{Gambaran Umum Tenaga Kerja}

\section{Indonesia di Malaysia}

Berdasarkan catatan Kedutaan Besar Republik Indonesia (KBRI) di Kuala Lumpur jumlah tenaga kerja Indonesia yang bekerja di Malaysia sekitar 2 juta orang. Dari jumlah tersebut, 1,2 juta di antaranya merupakan TKI resmi yang memiliki izin bekerja. Sementara sisanya 
yakni, sekitar 800.000 orang dinyatakan berstatus ilegal (Kompas 14 April 2008). Sementara pemerintah Malaysia sendiri, berdasarkan data yang dikemukakan Jabatan Perangkaan Malaysia, sampai akhir tahun 2007 menyebutkan ada 1.728.734 tenaga kerja asing yang bekerja secara sah di negara tersebut (Utusan Malaysia 24 Juni 2008).
Jika dibandingkan dengan tenaga kerja asing lainnya di Malaysia, jumlah tenaga kerja Indonesia merupakan yang terbesar sehingga menduduki tempat teratas dalam daftar komposisi ketenagakerjaan. Mereka terutama bekerja pada sektor-sektor seperti: Pembantu rumah tangga, pekerja bangunan, perkebunan, pabrik, dan pelayanan (jasa).

Tabel 1

Komposisi Tenaga Kerja Asing Menurut Negara Asal (\%)

$\begin{array}{lccrrr}\text { Negara Asal } & \mathbf{2 0 0 3} & \mathbf{2 0 0 4} & \mathbf{2 0 0 5} & \mathbf{2 0 0 6} & \mathbf{2 0 0 7} \\ \text { Indonesia } & 63,8 & 65,7 & 66,5 & 68,4 & 69,4 \\ \text { Nepal } & 9,7 & 0,1 & 9,2 & 7,3 & 0,1 \\ \text { Bangladesh } & 8,4 & 27,0 & 8,0 & 17,1 & 24,6 \\ \text { India } & 5,6 & 3,2 & 4,5 & 4,0 & 3,0 \\ \text { Myanmar } & 4,3 & 0,9 & 4,2 & 1,0 & 0,5 \\ \text { Filipina } & 0,6 & 1,8 & 1,1 & 1,0 & 1,2 \\ \text { Thailand } & 0,9 & 0,5 & 1,0 & 0,4 & 0,4 \\ \text { Pakistan } & 0,2 & 0,6 & 0,1 & 0,4 & 0,5 \\ \text { Negara Lain } & 6,5 & 0,2 & 5,4 & 0,4 & 0,3\end{array}$

$\begin{array}{llllll}\text { JUMLAH } & 100,0 & 100,0 & 100,0 & 100,0 & 100,0\end{array}$

Sumber: Jabatan Perangkaan Malaysia 2007, dalam Utusan Malaysia 24 Juni 2008.

Tabel 2

Komposisi Bidang Pekerjaan TKI di Malaysia 2007

Bidang Pekerjaan

Perkebunan/Pertanian

Pembantu rumah tangga

Pekerja bangunan dan pabrik

Pelayanan (rumah makan, kedai, dll.)

Total

Sumber: Jabatan Perangkaan Malaysia 2007 dalam Utusan Malaysia, 14 April 2008.
Jumlah

394.458

294.784

417.796

1.107.038 
Di luar itu, terdapat sejumlah kecil orang-orang Indonesia, kelompok profesional, yang bekerja pada sektorsektor formal dengan keahlian khusus yang tinggi dalam bidang-bidang: Pertambangan, perminyakan, penerbangan, teknologi kedirgantaraan, kedokteran, dosen dan peneliti. Secara kasar, jumlah tenaga kerja asing di Malaysia, baik yang legal maupun ilegal diperkirakan mencapai sekitar 3 juta orang. Jumlah tersebut tentu saja cukup besar, mencakup kurang lebih 9,3\% dari total 28 juta penduduk Malaysia (Azis 2005: 17). Besarnya rasio perbandingan antara pekerja asing dan penduduk setempat, dalam skala tertentu dirasakan tidak nyaman.

\section{Tenaga Kerja Ilegal}

Banyaknya jumlah tenaga kerja ilegal, khususnya Indonesia, di Malaysia telah menjadi isu yang nyaris berulang setiap tahun. Status ilegal tenaga kerja Indonesia di Malaysia terjadi dalam berbagai cara atau sebab. Pertama, adalah tenaga kerja tersebut secara sengaja masuk ke wilayah Malaysia tanpa menggunakan dokumen yang sah melalui jalur tidak resmi di wilayah-wilayah perbatasan.

Kedua, mereka masuk ke Malaysia dengan visa kunjungan atau wisata yang kemudian menyusup dan bekerja di sana.
Ketiga, tenaga kerja ilegal itu bisa terjadi jika masa berlaku dokumen kerjanya habis, namun yang bersangkutan tetap bertahan di Malaysia, berpindah pekerjaan, atau melarikan diri. Keempat, adalah tenaga kerja yang semula legal yang bekerja pada suatu majikan, tetapi karena berbagai sebab, mulai dari penganiayaan, penyiksaan, penipuan, pelecehan seksual, dilacurkan, gaji tidak dibayar, jam kerja tanpa batasan pasti, beban kerja yang berat serta upah yang rendah, kemudian melarikan diri sehingga berubah status menjadi ilegal. Jadi dapat disimpulkan bahwa, keberadaan tenaga kerja ilegal itu terjadi karena dua sebab, yakni sebagai pilihan yang disengaja dan akibat yang tidak disengaja.

\section{Dari Kebutuhan ke Implikasi}

Sejak dahulu, pembangunan Malaysia tidak dapat dilepaskan dari peranan para pekerja asing. Masuknya buruh asing ke negara tersebut bersamaan dengan berlakunya penjajahan Inggris pada abad 19, yang membuka tambang-tambang timah serta perkebunan karet di beberapa wilayah dengan mendatangkan para pekerja dari Cina dan Sri Lanka maupun India Selatan (Manaf 2001: 47). Di samping itu, terdapat pula migran alamiah para penduduk dari wilayah Nusantara 
seperti; Jawa, Bugis, Minang, dan lain-lain yang sengaja berhijrah mencari kehidupan yang lebih baik. Namun berbeda dengan imigran yang didatangkan Inggris, kelompok etnis ini lebih banyak bekerja sendiri, terutama dengan membuka ladang maupun berdagang.

Sejarah kemasukan buruh asing ini terus berlanjut sampai dengan ketika Malaysia merdeka. Hal tersebut dilandasi oleh fakta akan kebutuhan tenaga kerja asing kasar yang cukup tinggi. Tidak sedikit kemudian di antara generasi awal pekerja Indonesia ini yang kemudian tinggal dan terus menetap di Malaysia. Selanjutnya, tahap kemasukan tenaga kerja Indonesia yang kedua adalah pada tahun 1980-an sampai dengan 1990-an di mana pemerintah Malaysia berusaha untuk mengontrol kemasukan pekerja asing dengan lebih selektif. Pembangunan Malaysia yang meningkat dengan pesat pada periode tersebut, mendorong terjadinya arus masuk pekerja migran asal Indonesia dalam jumlah yang cukup besar. Bahkan, tidak sedikit di antaranya yang masuk dengan cara-cara yang tidak resmi. Mereka inilah, yang menimbulkan persoalan tersendiri.

\section{Implikasi Ekonomi}

Meskipun secara umum, tenaga kerja asing memberikan sumbangan penting bagi pembangunan ekonomi Malaysia yang pesat, namun tak dapat dipungkiri bahwa kehadiran TKI ilegal menimbulkan akibatakibat tersendiri dalam bidang ekonomi di negara tersebut. Pertama, adalah meningkatnya tingkat pengangguran di masyarakat. Berbagai pekerjaan yang seharusnya dapat diisi oleh pekerja setempat direbut oleh TKI ilegal karena sebagian majikan ada yang lebih suka mengambil TKI ilegal dengan gaji yang murah (Awang 1998: 62).

Kedua, kehadiran TKI ilegal secara ekonomi memperlemah posisi daya tawar gaji pekerja setempat. Dengan adanya TKI ilegal, pekerja setempat sukar untuk mendapatkan kenaikan gaji yang memadai.

Ketiga, terjadinya aliran dana keluar yang cukup besar dari Malaysia. Dipastikan hampir setiap bulan para tenaga kerja Indonesia akan mengirim uang mereka kepada keluarganya di kampung halaman. Dengan jumlah tenaga kerja yang mencapai kurang lebih 2 juta orang maka diperkirakan ada trilyunan uang yang dikirim dari Malaysia ke Indonesia setiap tahun. 


\section{Implikasi Sosial}

Di bidang sosial, ada beberapa implikasi penting yang ditimbulkan oleh tenaga kerja ilegal. Menurut Hasyim Anuwar (2003: 37-39) ada beberapa isu sosial yang seringkali dapat dikaitkan dengan mereka. Pertama, keberadaan TKI ilegal sering dikaitkan dengan masalah "pemukiman liar" atau "pemukiman kumuh”. Banyak di antara pendatang ilegal ini, yang mendirikan rumah-rumah liar di sejumlah tempat, yang dapat mengganggu kepentingan umum. Kedua, penyebaran narkotika. Meskipun pada dasarnya penduduk Malaysia sendiri banyak yang terlibat dalam penggunaan dan perdagangan narkoba, sehingga pada tahap yang cukup mengkhawatirkan, namun tidak dapat dipungkiri bahwa peredaran barang haram tersebut juga turut melibatkan warga asing. Ketiga, TKI, khususnya TKI ilegal kerap dikaitkan dengan masalah penyebaran penyakit. Kondisi mereka yang sejak awal masuk Malaysia tidak sehat sepenuhnya, karena tidak melalui uji kesehatan memadai di negara asal, menyebabkan sukar untuk mengontrol kesehatan mereka. Kondisi tersebut diperparah dengan bidang dan lingkungan kerja yang dimasuki, yang kotor, kasar, berbahaya, serta cara hidup mereka yang kurang sehat.
Keempat, TKI ilegal dikaitkan dengan penyakit-penyakit sosial tertentu. Salah satu contohnya adalah judi dan permainan ketangkasan dalam berbagai bentuknya.

\section{Implikasi Keamanan}

Kedatangan tenaga kerja Indonesia pada masa awal-awal pembangunan Malaysia sampai tahun 1970-an tidak banyak mendatangkan masalah. Jumlah mereka yang tidak terlalu banyak dan sifat mereka yang mudah diasimilaskan dengan penduduk setempat menyebabkan para buruh migran awal lebih mudah diterima.

Akan tetapi, malangnya, keadaan tersebut tidak berjalan sebagaimana diharapkan. Setelah era 1970-an, jumlah pekerja Indonesia meningkat dengan pesat seiring dengan pembangunan ekonomi Malaysia. Dalam pandangan sebagian pengamat Malaysia, gelombang pekerja migran yang baru ini agak berbeda dengan sebelumnya. Karena jumlah mereka yang besar dan terus bertambah, sifat mereka agak sukar diasimilasikan. Bahkan yang terjadi justru sebaliknya. Mereka terkesan berusaha mengekalkan kebudayaan mereka sendiri dan mencoba menegaskan diri sebagai kelompok yang lain dari etnik mayoritas Melayu (Burhanuddin 2001: 27). Pada tahap tertentu kelompok ini bahkan 
mampu mencorakkan dan mempengaruhi budaya setempat.

Dalam beberapa hal, kelompok pekerja Indonesia ini menimbulkan masalah, khususnya di bidang keamanan. Keterangan resmi pemerintah Malaysia menyebutkan bahwa sepanjang tahun 2007 tindak kejahatan yang dilakukan warga asing mencakup: 25,1\% warga asing terlibat dalam kasus pembunuhan; $24,8 \%$ percobaan membunuh; $32,6 \%$ perampokan secara berkelompok; dan 17,5\% perampokan bersenjata secara perorangan. Hampir separuh lebih dari kasus-kasus tersebut dilakukan orang Indonesia (Utusan Malaysia 11 Mei 2008).

Di kalangan aparat kepolisian Malaysia sudah umum dikenal nama-nama gang penjahat dari Indonesia yang sering beroperasi, seperti; "gang Sumatera", "gang Palembang", "gang Aceh", dan beberapa lagi yang lain yang sudah beberapa kali ditumpas.

\section{Kebijakan dan Langkah Malaysia}

\section{Kebijakan}

Dari pihak pemerintah Malaysia, selama ini telah dicoba untuk memecahkan persoalan TKI ilegal dengan pihak Indonesia melalui beberapa instrumen. Salah satunya adalah melalui perjanjian.
Sepanjang tahun 1980-an dan 1990-an ada sejumlah perjanjian penting yang berhasil disepakati kedua belah pihak (Yaacob 2000: 51-54). Pertama, Pada tahun 1984 misalnya dicapai kesepakatan yang menentukan pekerja sektor perkebunan dan pembantu rumah tangga Indonesia untuk dapat dibawa masuk ke Malaysia secara legal. Perjanjian ini memberikan peluang kemudahan baik dari segi perijinan maupun administrasi bagi Indonesia memasok lebih banyak pekerjanya di kedua sektor tersebut.

Akan tetapi, perjanjian itu tidak banyak berarti, karena kedatangan TKI ilegal tetap saja tinggi. Pemerintah Malaysia yang agak kecewa dengan hasil yang diharapkan kemudian mengambil langkah berikutnya yang kedua tahun 1989-1991, berupa Program Pemutihan bagi TKI illegal Indonesia. Program ini berisi ketentuan yang mewajibkan TKI ilegal untuk mendaftarkan diri dan mengubah status mereka dari pekerja ilegal menjadi pekerja yang sah. Program Pemutihan di atas kemudian disusul dengan kebijakan yang ketiga, yakni Program Pengampunan untuk tenaga kerja ilegal tahun 1991-1992 untuk tenaga keja ilegal di sektor pembantu rumah tangga dan kemudian diperluaskan ke sektorsektor lainnya. 
Pada tahap tertentu, meskipun tidak maksimal, program ini ternyata cukup berhasil mendorong para TKI ilegal untuk mendaftarkan diri dan mengubah statusnya menjadi legal. Meskipun demikian, masih ada sebagian TKI yang enggan melaporkan diri, dan tetap dalam status semula sebagai pekerja ilegal. Akibatnya, pemerintah Malaysia melakukan gerakan operasi besar-besaran yang disebut dengan, Operasi Nyah (Ops Nyah). Operasi Nyah dilakukan untuk menangkap para tenaga kerja illegal yang kemudian akan dipulangkan ke Indonesia (Yaacob 2000: $67)$.

Tindakan pemerintah Malaysia tersebut mendapatkan reaksi dari pihak Indonesia, yang untuk sementara waktu meminta agar aparat Malaysia menahan diri dan tidak serta merta memulangkan tenaga kerja ilegal yang tetangkap. Dialog antara Jakarta dan Kuala Lumpur akhirnya sepakat bahwa pemulangan itu akan dilakukan secara bertahap sambil menunggu kesiapan Indonesia (Yaacob 2000: 71).

Ternyata usaha untuk melakukan pengusiran secara besar-besaran terhadap TKI ilegal kembali dilakukan, ketika pada bulan Juli 1997 Malaysia dihantam krisis ekonomi. Pihak berkuasa setempat, kembali menggelar Operasi Nyah, berusaha keras membendung keberadaan maupun masuknya tenaga kerja ilegal baru dari Indonesia yang juga sedang mengalami krisis yang sama. Dalam jangka pendek operasi ini dapat dikatakan berhasil. Namun kemudian, sesudah ekonomi Malaysia berangsur-angsur pulih dan sektor pembangunan normal kembali, kehadiran TKI ilegal tetap saja tinggi. Sejumlah pihak dalam pemerintahan mengusulkan agar kebijakan pengambilan tenaga kerja dari Indonesia ditinjau kembali. Mereka yakin bahwa sektorsektor tertentu yang selama ini mempekerjakan TKI tidak akan lumpuh, karena Malaysia dapat mengambil sumber tenaga kerja dari negara lain (Salleh 2008: $61)$.

Namun, rencana itu tidak berlanjut lebih jauh dan pada tahun 2002 pemerintah lebih memilih untuk kembali menerapkan kebijakan pengampunan. Dalam Program Pengampunan kali ini para TKI ilegal diberi kesempatan untuk kembali ke tanah air dan mengurus surat-surat bekerja secara sah di tanah air jika masih berminat bekerja kembali. Selepas itu, pemerintah melancarkan operasi besar-besaran memburu tenaga kerja ilegal untuk ditahan. Kejadian yang sama kemudian berulang kembali di tahun 2006. Ribuan tenaga kerja ilegal dari berbagai negara terpaksa 
harus dipulangkan dari Malaysia karena tidak memiliki dokumen yang lengkap. Pihak imigrasi Malaysia memperkirakan 278.640 orang tenaga kerja illegal dipulangkan dari Malaysia. Dari jumlah tersebut, rakyat Indonesia menccatat jumlah tertinggi yakni $82,7 \%$, India $7 \%$, Bangladesh 6,3\% (Salleh 2008: 67). Pemerintah Indonesia yang mencoba melakukan pendekatan, untuk mencegah pemulangan itu, tidak berkutik menghadapi ketegasan sikap Malaysia.

\section{Langkah}

Di samping serangkaian kebijakan yang dilakukan di atas, pemerintah Malaysia mencoba mengambil langkah penting dengan pihak Indonesia. Menurut Nik Suhaila Abdurrahman (2008:48-53) ada beberapa langkah yang ditempuh yakni: Pertama dengan melakukan perundingan. Sepanjang tahun 2000-an, telah ada beberapa ada kesepakatan yang ditandatangani menyangkut nasib tenaga kerja Indonesia di negara tersebut.

Kedua, pada tahun 2005 dicapai kesepakatan (MOU) antara pihak Malaysia dan Indonesia mengenai kenaikan upah, asuransi, keselamatan, kesehatan, biaya pendidikan, serta hak bercuti bagi para tenaga kerja Indonesia di Malaysia.
Pada tahun 2006 pemerintah Malaysia dan Indonesia menyepakati adanya butiran perjanjian tentang pengurusan administrasi pengambilan tenaga kerja Indonesia, baik dari agen, sampai pengurusan di imigrasi. Di samping itu, juga disepakati adanya pos-pos layanan bagi pengurusan pengambilan tenaga kerja yang melibatkan pihak Malaysia di sejumlah kota-kota tertentu di Indonesia; pemberian layanan hukum; penanganan pendidikan anak-anak tenaga kerja; jaminan kesehatan; dan program pelatihan.

Ketiga, adalah dengan menerapkan undang-undang yang lebih ketat. Adanya berbagai kejadian kerusuhan dan tindakan kriminal yang melibatkan tenaga kerja asing mendorong pihak pemerintah Malaysia lebih bersikap waspada dengan menerapkan undang-undang yang lebih ketat. Cara tersebut misalnya ditempuh dengan mengubah Undang-Undang Imigrasi 1959/1963 dengan UndangUndang Imigrasi yang baru di tahun 2002.

Mereka dapat dikenakan hukuman penjara dan cambuk. Dapat pula didenda sehingga RM 10.000 (Rp. 35.000.000) serta cambuk tidak lebih dari enam kali. Sedangkan majikan yang mempekerjakan akan dikenakan denda antara RM 10.000RM 50.000 (Rp. 35.000.000-160.000.000) bagi setiap tenaga kerja ilegal yang 
dipekerjakan atau dipenjara tidak lebih dari 12 bulan ataupun kedua-duanya sekali. Selain itu, majikan juga akan menerima hukuman cambuk sampai enam kali jika ketahuan mempekerjakan lebih dari lima pekerja selain dari hukuman penjara antara enam bulan hingga lima tahun.

Tentu saja, untuk sebagian, hukuman di atas dianggap kelewat berat. Sejumlah lembaga swadaya masyarakat dan pegiat hak asasi manusia melihat sebagai tidak berperikemanusiaan.

\section{Sikap dan Respon Indonesia}

Menanggapi berbagai kebijakan yang dilakukan pemerintah Malaysia di atas, sesungguhnya sikap dan respon Indonesia dapat dibagi menjadi dua. Pertama, adalah sikap dan respon resmi pemerintah. Kedua, sikap dan respon rakyat Indonesia. Pada mulanya, sikap pemerintah Indonesia terhadap berbagai bentuk kebijakan Malaysia menyangkut TKI di sana tidaklah begitu keras, kecuali pada kasus-kasus tertentu seperti; pelaksanaan hukuman mati terhadap beberapa orang yang pernah terjadi, seperti, Basri Masse di tahun 1990an, dan beberapa lagi yang lainnya. Sikap dan reaksi Indonesia dapat dikatakan masih terukur dan dalam batas-batas tertentu cukup lunak. Keadaan tersebut didukung oleh hubungan yang baik antara rejim
Soeharto di Indonesia dan Perdana Menteri

Mahathir Mohamad di Malaysia (Hardiyanto 2007: 43).

Akan tetapi, suasana itu berubah selepas tahun 2000-an, terutama ketika pemerintah Malaysia bertindak lebih tegas dan keras dalam cara-cara penanganan tenaga kerja asing di negara tersebut. Insiden awal adalah aksi kerusuhan yang dilakukan para TKI di Nilai wilayah Negeri Sembilan tahun 2002 yang ditangani dengan keras oleh pemerintah Malaysia. Pemerintah Indonesia mulai khawatir dengan tindakan berlebihan aparat atas kejadian tersebut. Meskipun demikian, Menteri Luar Negeri Hassan Wirayuda meminta agar pemerintah Malaysia dapat menahan diri dan tidak menghakimi pada semua pekerja Indonesia secara semena-mena, hanya karena ulah segelintir TKI (Hardiyanto 2007: 44)

Tindakan tegas selanjutnya adalah diterapkannya hukuman cambuk berdasarkan Undang-Undang Imigrasi tahun 2002. Cara Malaysia menggunakan hukuman ini dipandang sebagai cara usang yang ketinggalan jaman dan tidak memperhatikan rasa kemanusiaan. Pemerintah Indonesia yang tidak bisa berbuat banyak, lagi-lagi hanya dapat berharap agar pihak aparat Malaysia bertindak adil dan berlaku selektif terhadap 
para TKI yang bersalah. Penerapan Undang-Undang tersebut sebagai pelengkap sekaligus susulan terhadap tindakan pemulangan ribuan tenaga kerja asing di Malaysia (Lesmana 2008: 17-18).

Sementara itu, pada tingkat masyarakat di Indonesia, reaksi terhadap penerapan hukuman cambuk dan pemulangan ribuan TKI sangat keras. Terjadi serangkaian demonstrasi di Jakarta yang dilakukan berbagai unsur masyarakat. Mulai dari aktifis perburuhan, mahasiswa, lembaga-lembaga swadaya masyarakat, maupun para tokoh politik. Berkali-kali mereka mendatangi Kedutaan Besar Malaysia. Mereka menuntut agar Malaysia tidak bersikap semena-mena terhadap para TKI di sana dan memperlakukan mereka secara manusiawi. Bahkan Ketua Majelis Permusyawaratan Rakyat, Amien Rais, seperti dipetik oleh media mengeluarkan pernyataan keras dengan mengatakan bahwa, hukuman cambuk yang diterapkan Malaysia sebagai hukum Abad Pertengahan yang ketinggalan jaman, tidak berperikemanusiaan, dan menyakiti hati rakyat Indonesia (Gatra 25 Agustus 2002)

Hal senada juga disampaikan oleh Menteri Tenaga Kerja dan Transmigrasi, Jacob Nuwa Wea, yang mengecam hukuman cambuk terhadap warganegara Indonesia sebagai bentuk penghinaan yang sesungguhnya tidak patut dilakukan negara seperti Malaysia. Pada sebagian kalangan terdapat pula pernyataan yang lebih keras, khususnya di kalangan politisi di Dewan Perwakilan Rakyat Republik Indonesia dan tokoh-tokoh partai poltik, yang menyatakan agar pemerintah mengkaji secara serius hubungannya dengan Malaysia, atau bahkan sekalian memutuskan hubungan diplomatik. Jika dicermati secara mendalam kebanyakan pendapat mereka lebih merupakan pendapat pribadi dan lebih bertendensi politik, yakni menaikkan citra politik mereka atau bahkan untuk kepentingan pemilu 2004 (Lesmana 2008: 24).

Di kalangan masyarakat, sasaran kekesalan juga ditumpahkan kepada pemerintah yang selama ini dianggap tidak becus dalam menangani masalah tenaga kerja. Respon pemerintah sangat lamban dibanding dengan tindakan tegas pemerintah Malaysia. Para TKI seakanakan memperjuangkan nasibnya sendiri di negeri orang.

Kegagalan pemerintah Indonesia dalam menangani terjadinya pemulangan tenaga kerja ilegal dari Malaysia berulang lagi pada tahun 2006. Pemerintah Malaysia menawarkan kembali dasar pengampunan dan memberi kesempatan kepada para TKI ilegal untuk pulang ke tanah air untuk 
mengurus dokumen-dokumen yang diperlukan. Akibatnya, ribuan orang TKI mengalir dari Malaysia melewati sejumlah titik penampungan yang sudah dipersiapkan, seperti: Dumai, Nunukan, Entikong, Tanjung Pinang, dan Belawan. Pada beberapa kesempatan pihak media melaporkan terjadinya keterlambatan penjemputan kapal pemerintah, jumlah penumpang kapal yang berlebih, penampungan yang penuh sesak, serta uang perjalanan ke daerah asal yang tidak memadai yang dilakukan masingi-masing pemerintah daerah. Belum lagi masih adanya terjadi pemerasan yang dilakukan sejumlah oknum di pelabuhan maupun penampungan pada TKI yang malang ini (Untoro 2008: 8)

Di lingkungan pemerintahan sendiri terjadi serangkaian silang pendapat tentang cara penanganan yang ditunjukkan dengan lemahnya koordinasi antar instansi terkait. Sejumlah kalangan politisi mengecam pemerintah sebagai tidak becus dalam menangani keadaan dan melakukan loby yang baik dengan pemerintah Malaysia. Anggota Komisi I DPR, misalnya, dalam rapat dengar pendapat dengan pemerintah menuding Menteri Tenaga Kerja dan Menteri Luar Negeri tidak dapat memfungsikan aparatnya secara baik (Untoro 2008: 32). Selain itu, sejumlah anggota fraksi di DPR dengan cerdik memanfaatkan momentum ini dengan melakukan kunjungan ke Malaysia dan meninjau basis-basis TKI di sana.

Pada kenyataannya, sikap dan reaksi Indonesia terhadap masalah TKI illegal di Malaysia tidak dapat dilepaskan dari kondisi politik kedua negara. Indonesia selepas mundurnya Presiden Soeharto tahun 1998 muncul sebagai negara demokratis, sementara Malaysia tetap sebagai negara otoriter, yang dalam prakteknya melahirkan corak masyarakat dan tipe kepemimpinan yang berbeda. Sifat dan karakter dasar kepolitikan yang berkembang di Indonesia pada gilirannya kemudian berimbas pada cara mereka dalam merespon setiap isu, yang dalam banyak hal berbeda dengan karakter dan corak masyarakat Malaysia.

Hal inilah yang seringkali menimbulkan perbedaan persepsi dan cara pandang. Selain itu, generasi kepemimpinan baru pasca Orde Baru tidaklah memiliki hubungan personal yang rapat dengan pucuk pimpinan di Malaysia, sebagaimana Soeharto-Mahathir di masa lalu. Padahal pendekatan informal dalam menangani berbagai masalah yang menyangkut kedua negara terkadang jauh lebih penting ketimbang pendekatan politik formal qua diplomasi. 
Jalan Keluar dan Langkah Penyelesaian Masalah TKI Ilegal

Usaha untuk menangani TKI ilegal haruslah dilihat dalam konteks yang menyeluruh. Jika mau ditangani dengan betul tentu dilakukan dari sumbernya. Dalam hal ini pihak pemerintah Indonesia sebetulnya lebih dituntut memperbaiki sistem ketenagakerjaannya. Salah satu langkah penting mesti dilakukan pemerintah adalah mempersiapkan calon tenaga kerja dengan membekali keterampilan, melalui pelatihan yang memadai agar kelak yang bersangkutan dapat bekerja dengan baik dan memenuhi standar kerja yang diinginkan majikan.

Selain itu, pemerintah perlu mempermudah cara dan proses pengurusan untuk mendapatkan permit bagi masyarakat yang akan bekerja di luar negeri. Namun, malangnya, selama ini yang terjadi justru oknum-oknum dalam birokrasi terkait, mulai dari Lurah, Kepolisian, Departemen Tenaga Kerja, Imigrasi, yang melibatkan agen pengerah tenaga kerja memanfaatkan situasi dengan cara memeras calon tenaga kerja yang mengurus dokumen-dokumen resmi. Pengurusan dokumen menjadi mahal, sehingga mendorong calon tenaga kerja untuk menggunakan jalan pintas yang mudah melalui jalur tidak resmi.
Nampaknya usaha untuk memperbaiki sistem penanganan TKI ke luar negeri perlu dilakukan dengan membentuk suatu badan otoritas baru, yang benar-benar serius dan bersih, agar berbagai pelanggaran yang selama ini terjadi dapat dilenyapkan. Sebab, selama ini, penanganan TKI oleh lembaga di bawah naungan Depnakertrans justru tidak membawa perbaikan berarti. Berbagai regulasi yang diterapkan, secara memalukan justru membawa dapat kontraproduktif terhadap TKI.

Hal lain yang perlu diperhatikan adalah upaya perlindungan dan jaminan hukum pada tenaga kerja di luar negeri. Di samping juga pemenuhan hak-hak keluarganya secara keseluruhan. Adanya penyiksaan terhadap TKI di Malaysia, atau TKI menghadapi sidang mahkamah tanpa pengacara hukum, sampai dihukum mati, dan lain-lain, menunjukkan keterlambatan pemerintah khususnya pihak Kedutaan serta Departemen Luar Negeri mengantisipasi keadaan.

Selama pemerintah tidak dapat menyediakan lapangan kerja yang memadai di dalam negeri, maka pilihan bekerja di luar negeri merupakan alternatif yang paling realistik. Namun yang nampak, kebijakan pemerintah bersikap ambivalen. Di satu pihak menyatakan TKI 
sebagai "pahlawan devisa" sementara di lain pihak pelayanan dan perlindungan terhadap TKI masih jauh dari yang diharapkan, sehingga tidak sukar kita menemukan munculnya kasus-kasus TKI bermasalah di luar negeri hampir setiap bulan. Jika kondisi ini dibiarkan pasti kita mempertanyakan sejauh mana kewenangan pemerintah dalam menegakkan otoritasnya dan melindungi warganya.

\section{Kesimpulan}

Berdasarkan uraian yang dikemukakan dalam kajian di atas dapat disimpulkan beberapa hal. Pertama, bahwa masalah tenaga kerja ilegal memberikan dampak bagi hubungan Indonesia-Malaysia. Meskipun sejauh ini hubungan kedua negara terus berlangsung dengan amat baik, namun isu TKI seringkali menjadi alat pemicu ketegangan hubungan secara tidak terduga.

Kedua, keberadaan TKI ilegal telah menimbulkan permasalahan serius di Malaysia. Usaha-usaha yang dilakukan pemerintahan negara itu dalam menangani TKI ilegal perlu dilihat dalam konteks yang lebih proporsional, meskipun pada tingkat tertentu tidak mengesampingkan adanya unsur ketidakbecusan oknumoknum pemerintah Malaysia dalam bertindak. Ketiga, pemerintah Indonesia perlu lebih serius, dan mengambil jalan pendekatan yang integratif, dalam memperbaiki penanganan sistem ketenagakerjaan. Mulai dari penyiapan tenaga kerja, perbaikan peraturan, penataan birokrasi kelembagaan, sampai kemampuan advokasi di lapangan.

\section{DAFTAR PUSTAKA}

\section{A. Daftar Buku}

Abdurrahman, Nik Suhaila, Kewujudan Buruh Asing dalam Pembangunan di Malaysia: Masalah dan Dilema, Kuala Lumpur: Sigma Press, 2008.

Adam, Ramlah, Gerakan Radikal Kiri di Malaysia, Kuala Lumpur: Dewan Bahasa, 2003.

Anuwar, Hasyim, Isu-Isu Sosial Semasa di Malaysia: Kajian Beberapa Aspek, Kuala Lumpur: UM Press, 2003.

Awang, Ahmad Burhan, Pekerja Asing dan Pembangunan di Malaysia: Manfaat dan Impak, Kuala Lumpur: Mutiara Sdn. Bhd., 1998.

Azis, Ungku, Malaysian Economic Development: Resources and Capacity, Kuala Lumpur: UM Press, 2005.

Burhanuddin, Zainol, Indonesian Migrant Worker and Malaysian Society, Kuala Lumpur: Sigma Press, 2001.

Hardiyanto, Heri, Tenaga Kerja Indonesia di Luar Negeri: Aspek-Aspek 
Pemberdayaan dan Masalah, Yogyakarta: Aditya Media, 2007.

Lesmana, Rudy, Merana di Negeri Sendiri, Ditindas di Negeri Orang: Nasib dan Derita TKI di Malaysia, Yogyakarta: Nyiur Hajau, 2008.

Majid, Suhaimi Abdul, Pendatang Haram, Buruh Asing, dan Masa Depan Malaysia: Kajian Semasa, Kuala Lumpur: Pena Emas, 2005.

Manaf, Azmah Abdul, Sejarah Sosial Masyarakat Malaysia, Kuala Lumpur: Utusan Publications \& Distributors Sdn Bhd, 2001.

Moleong, Lexy J., Metode Penelitian Kualitatif, Bandung: Remaja Rosdakarya, 1996.

Muniandy, Kunaseelan, Malaysia Foreign Policy 1957-1990, Kuala Lumpur: Zeed Books, 1996.

Omar, Rusdi. Malaysia Foreign Policy: From Tunku to Mahathir, Kuala Lumpur: Pinma Publications, 2001.

Salleh, Mohd. Zahman, Masalah Pekerja Asing di Malaysia: Perspektif dan Cabaran, Kuala Lumpur: UM Pres, 2008.

Sarji, Ismail, Migrant Worker in Southeast Asia, Kuala Lumpur: Zeed Books, 2001.
Suryadinata, Leo, Politik Luar Negeri Indonesia di Bawah Soeharto, Jakarta: LP3ES, 1991.

Untoro, Hesti, Berburu Ringgit Ke Negeri Seberang: Tinjauan Atas Kegagalan Pemerintah Terhadap Perlindungan TKI di Luar Negeri, Yogyakarta: Sketsa Masa, 2008.

Yaacob, Syamsuddin Yaacob, "Polisi dan Tindakan Kerajaan dalam Menangani Isu Pekerja Indonesia" dalam Baharom Hassan, Pembangunan Ekonomi Malaysia: Dari Kemelesetan Menuju Kebangkitan Semula, Kuala Lumpur: Mutiara, 2000.

\section{B. Daftar Majalah dan Koran}

Gatra, 25 Agustus 2002

Gatra, 14 September 2002

Kompas, 16 Agustus 2002

Kompas, 18 Agustus 2002

Kompas, 29 Februari 2005

Kompas, 27 April 2008.

Kompas, 4 Desember 2008

Utusan Malaysia, 11 Mei 2008

Utusan Malaysia, 13 April 2008

Utusan Malaysia, 14 April 2008

Utusan Malaysia, 24 Juni 2008

Utusan Malaysia, 24 Juni 2008. 